\title{
Coccidioides Antibody Measurement
}

National Cancer Institute

\section{Source}

National Cancer Institute. Coccidioides Antibody Measurement. NCI Thesaurus. Code C111160.

The determination of the amount of coccidioides antibody present in a sample. 